\title{
Trophic structure of macroinvertebrates in tropical pasture streams
}

\author{
Estrutura trófica de macroinvertebrados em riachos tropicais de pastagem
}

\author{
Bruna Neves da Silveira-Manzotti ${ }^{1}$, Angelo Rodrigo Manzotti ${ }^{1 *}$, \\ Mônica Ceneviva-Bastos ${ }^{2}$ and Lilian Casatti ${ }^{1}$
}

${ }^{1}$ Laboratório de Ictiologia, Departamento de Zoologia e Botânica, Instituto de Biociências, Letras e Ciências Exatas - IBILCE, Universidade Estadual Paulista - UNESP, Rua Cristóvão Colombo, 2265, CEP 15054-000, São José do Rio Preto, SP, Brazil

${ }^{2}$ Laboratório de Biologia Aquática, Departamento de Ciências Biológicas, Faculdade de Ciências e Letras - FCL, Universidade Estadual Paulista - UNESP, Avenida Dom Antônio, 2100, CEP 19806-900, Assis, SP, Brazil *e-mail: armanzotti@gmail.com

Cite as: Silveira-Manzotti, B.N. et al. Trophic structure of macroinvertebrates in tropical pasture streams. Acta Limnologica Brasiliensia, 2016, vol. 28, e15.

Abstract: Aim: The aim of this study was to describe the diet of stream macroinvertebrates and to determine their trophic groups. Methods: Invertebrates were sampled with D nets in three pasture streams. They were identified to genus level and submitted to gut content analysis, except for fluid feeders such as hemipterans, to which diet data was obtained from the literature. Trophic groups were determined based on a similarity analysis using the Bray-Curtis similarity coefficient. Results: Five trophic groups were defined: fine-detritivores (feed mostly on fine particulate organic matter - FPOM), coarse-detritivores/herbivores (feed mostly on coarse particulate organic matter - CPOM - and plant material), omnivores, specialist-predators (prey upon aquatic insects only), and generalist-predators. Ephemeroptera, Diptera (except Tanypodinae), Coleoptera, and Trichoptera (except Smicridea) were detritivores. The caddis Macronema (Trichoptera) fed exclusively on plant detritus and Tanypodinae and Smicridea were classified as omnivores. The odonate families Calopterygidae and Gomphidae were classified as specialist-predators, while Macrobrachium (Decapoda), Belostoma, and Limnocoris (Hemiptera) were generalist-predators. Conclusions: The great quantity and frequency of occurrence of FPOM consumed by most taxa highlight the importance of this food resource for macroinvertebrate communities from tropical streams. Furthermore, observed variations on trophic group assignment for some taxa indicate the generalist and opportunistic nature of these aquatic invertebrates. Such findings reinforce the importance of conducting gut content analysis on macroinvertebrates to understand their role in the structure and functioning of tropical streams.

Keywords: macroinvertebrate diet; detritus; feeding groups; aquatic insects; lotic system.

Resumo: Objetivos: O objetivo deste estudo foi descrever a dieta de macroinvertebrados aquáticos de riachos e determinar seus grupos tróficos. Métodos: Os invertebrados foram amostrados com rede $\mathrm{D}$ em três riachos localizados em áreas de pastagens. Eles foram identificados ao nível de gênero (com exceção da família Chironomidae) e submetidos a análises de dieta, exceto os Hemiptera sugadores, cuja dieta foi obtida a partir da literatura. Os grupos tróficos foram determinados por uma análise de similaridade utilizando o coeficiente de similaridade de Bray-Curtis. Resultados: Cinco grupos tróficos foram definidos: detritívoro-fino (dieta baseada em matéria orgânica particulada 
fina-FPOM), detritívoro-grosso/herbívoro (consumindo principalmente matéria orgânica particulada grossa - CPOM - e material vegetal), onívoro, predador-especialista (dieta especializada em inseto aquático) e predador-generalista. Ephemeroptera, Diptera (exceto Tanypodinae), Coleoptera e Trichoptera (exceto Smicridea) representam os detritívoros. Macronema (Trichoptera) foi o único táxon que se alimentou exclusivamente de material vegetal e Tanypodinae e Smicridea foram classificados como onívoros. As famílias Calopterygidae e Gomphidae foram classificadas como predador-especialista e Macrobrachium (Decapoda), Belostoma e Limnocoris (Hemiptera) como predador-generalista. Conclusóes: A grande quantidade e frequência de ocorrência de FPOM consumido pela maioria dos táxons demonstram a importância desse recurso alimentar para as comunidades de macroinvertebrados de riachos tropicais. Além disso, a variação nos grupos tróficos observada em alguns táxons reforça a natureza generalista e oportunista dos invertebrados aquáticos. Tais achados reforçam a importância de realizar análises de dieta para compreender o papel ecológico das espécies na estrutura e funcionamento dos riachos tropicais.

Palavras-chave: dieta de macroinvertebrados; detrito; grupos alimentares; insetos aquáticos; sistema lótico.

\section{Introduction}

Streams ecosystems support a wide range of taxonomic groups, such as plants (moss, ferns, aquatic macrophytes), algae, fungi, bacteria, planktonic organisms, invertebrates (insects, mollusks, crustaceans), and vertebrates (fish, amphibians, reptiles, mammals) (Allan \& Castilho, 2007). Among the aquatic fauna, macroinvertebrates are one of the most representative groups for presenting wide distribution and high abundance and taxonomic diversity. They are involved in many lotic ecosystem processes, such as nutrient cycling, energy flow and organic matter processing, playing an important role in both aquatic and adjacent terrestrial food webs (Malmqvist, 2002; Nakano \& Murakami, 2001; Bispo et al., 2006; Clarke et al., 2008).

Therefore, there is a growing need to study macroinvertebrate biology to better understand the functioning of stream ecosystems and to contribute to their management, directing conservation and mitigation measures (Moulton, 1998; Wright \& Covich, 2005; Gonçalves Junior et al., 2006; Wantzen \& Wagner, 2006). Nevertheless, such understanding is limited by practical problems that range from the difficulty to identify macroinvertebrate immature stages, even at genus level, to the scarcity of available morphological and behavioral data (Oliveira \& Froehlich, 1997).

According to Vannote et al. (1980), the riparian forests of headwater streams play a key role in structuring aquatic communities and influence instream nutrient dynamics. The replacement of such vegetation by a pasture matrix deprives streams of allochthonous inputs of nutrients and organic matter, leading to changes in overall trophic structure (Rodrigues \& Leitão Filho, 2000). Since feeding habits can influence many aspects of an organism, such as life cycle, habitat use and behavior, knowing their trophic ecology is fundamental to understand how biological communities are organized and how they respond to changes in the environment (Ricklefs, 2010; Rooney et al., 2006). Thus, the trophic approach can also be used as a tool to access the ecological processes that underlie stream ecosystem structure and function (Gessner \& Chauvet, 2002; Pascoal et al., 2005; Cummins et al., 2005).

Notwithstanding, most studies of aquatic insect trophic ecology conducted in tropical streams use a literature-based functional feeding group classification, which was proposed for macroinvertebrates from temperate ecosystems. Consequently, they assume that taxa that belong to the same genus (or even family) have the same feeding habits and food selection mechanisms in both temperate and tropical ecosystems (Mathuriau \& Chauvet, 2002; Gonçalves Junior et al., 2006, Couceiro et al., 2011; Callisto et al., 2001; Oliveira \& Nessimian, 2010). Although this assumption can be occasionally correct, it fails to consider the functional plasticity of Neotropical invertebrates, misguiding conclusions concerning their roles in aquatic ecosystems and underestimating the importance of food resources as detritus or bryophytes (see Dangles, 2002; Ocon et al., 2013 for examples).

Except for a few recent studies that included macroinvertebrate diet analysis in Neotropical streams (e.g. Motta \& Uieda, 2004; Carvalho \& Uieda, 2009; Ceneviva-Bastos \& Casatti, 2014; Ramírez \& Gutiérrez-Fonseca, 2014), empirical studies about their trophic ecology are still quite limited. Since information on tropical macroinvertebrates morphology and behavior is also 
limited and because their diet can vary according to local conditions, gut content analysis is certainly a more accurate way to access their trophic role than using functional feeding groups from the literature, at least until a classification is available to tropical taxa (Motta \& Uieda, 2004; Boulton et al., 2008; Boyero et al., 2009; Cheshire et al., 2005). In this context, our aim was to determine macroinvertebrate trophic groups based on diet analysis, contributing to the growing dataset on their trophic ecology and feeding behavior in tropical streams.

\section{Methods}

\subsection{Study area}

The study was conducted in three streams (S1, S2 and S3) located in the Northwest region of São Paulo State, Brazil (Figure 1), within the São José dos Dourados and Turvo-Grande river basins. Climate in the region is hot tropical, with average maximum temperature of $32{ }^{\circ} \mathrm{C}$, average minimum temperature of $13{ }^{\circ} \mathrm{C}$, average annual precipitation from 1,300 to $1,800 \mathrm{~mm}$ (Silva et al., 2007), and two well-defined seasons. The rainy season is from October to March (85\% of annual average precipitation) and the dry season from April to September (IPT, 2000).

The study region is reckoned as the most deforested and fragmented of São Paulo State, with remnants of native vegetation of $9 \%$ (Kronka et al., 1993) of which only $3.3 \%$ and $3.7 \%$ remain in the São José dos Dourados and Turvo-Grande river basins, respectively (Nalon et al., 2008). The rest is predominantly occupied by pasture and sugar-cane plantations, including the riparian areas (Silva et al., 2007). The studied streams were of low order and presented high structural similarity, with narrow channel, low depth, lack of riparian forest, sandy substrate and abundant grass on the banks, configuring typical pasture streams (Casatti et al., 2009; Teresa \& Casatti, 2010).

\subsection{Samplings and analysis}

Samplings were conducted within three 5-m reaches of each stream. Reaches were first isolated by placing block nets ( $3 \mathrm{~mm}$ mesh) in their upstream and downstream limits. Macroinvertebrates were sampled with standardized effort of three D net (250 $\mu \mathrm{m}$ mesh) passes along the entire reach, exploring all microhabitats present. The material retained by the block nets was also collected and all samples were fixed in $70 \%$ ethanol solution. Invertebrates caught were identified to genus level (except for Chironomidae, which were identified to subfamily level) using taxonomic keys (Froehlich, 2007; Passos et al., 2007; Domínguez \& Fernández, 2009; Mugnai et al., 2010; Segura et al., 2011).

Diet analysis was performed in ten specimens of each taxon of each stream; when less than ten specimens were sampled, all specimens were analyzed. Guts were removed through ventral incision and set on slides for the identification of gut contents under microscope. Reticule lens were used to help visual estimation of the percentage that each food item occupied from total gut contents. The diet of hemipterans could not be determined because they are fluid-feeders (Nieser \& Melo, 1997). Gut contents were grouped into seven categories: fine particulate organic matter (FPOM), coarse particulate organic matter (CPOM) and plant material, fungi, filamentous algae, unicellular or colonial algae, aquatic insects, and other animals.

The percentages of occupation of food items in the guts of individuals belonging to a same taxon were averaged to represent the diet of that

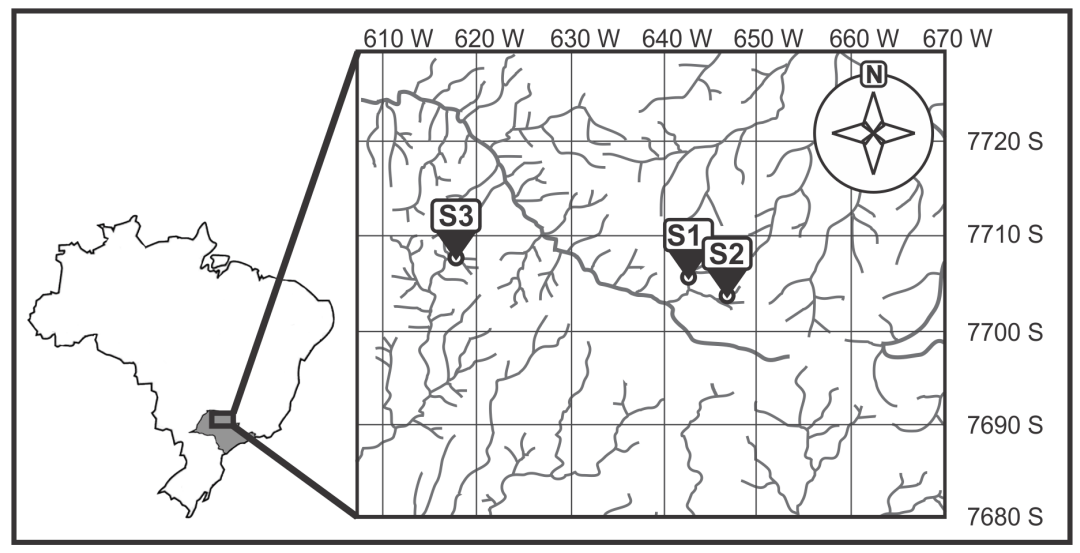

Figure 1. Map of the study area highlighting São Paulo State and the location of the studied streams (S1-S3) within the watershed. Numbers indicate UTM values (22K). 
taxon. Data were pre-treated with a square root transformation to stabilize variances (Clarke \& Gorley, 2006), and a similarity analysis was conducted, using the Bray-Curtis coefficient, to determine the trophic groups based on a cut of $70 \%$ similarity. Although such cut seems quite high, it was chosen for best describing the use of food resources by macroinvertebrates, since many of them predominantly fed on a single item.

\section{Results}

A total of 17,397 macroinvertebrate specimens belonging to seven orders and 14 families was sampled. Insects represented 13 of the 14 families and the most representative orders were Diptera (with $82.5 \%$ of the total abundance), Ephemeroptera $(11.3 \%)$ and Coleoptera (3.8\%). The family Chironomidae (Diptera) was also the most numerous, representing $81.1 \%$ of total abundance, followed by the mayflies Baetidae $(8.3 \%)$ and
Leptohyphidae (2.2\%) and Elmidae beetles (3.8\%). Other families were less abundant, representing less than $5 \%$ of total abundance.

In general, fine particulate organic matter (FPOM) was the most consumed food item, representing $71.5 \%$ of overall species diets and being frequent in the diet of all taxa, except Progomphus and Peruviogomphus. In most occurrences, FPOM was the most abundant food item in association to other resources. The 'aquatic insects' was the second most representative resource (19.9\%). It was mainly represented by remnants of midges and mayflies, which were frequently consumed by odonates and shrimps. Coarse particulate organic matter and plant material represented $5.5 \%$ of the consumed items and were mostly found in guts of caddisflies. The remaining food items were registered in low percentages in gut contents, computing less than $5 \%$ of all items consumed. The diet of each taxon is provided with further detail in Table 1.

Table 1. List of sampled macroinvertebrates, number of analyzed specimens $(\mathrm{N})$ and representativeness $(\%)$ of each food item in their diet. FPOM = fine particulate organic matter; $\mathrm{CPOM}=$ coarse particulate organic matter and plant material; FUN = fungi; $\mathrm{AI}=$ aquatic insects; $\mathrm{NAI}=$ Non aquatic insects; $\mathrm{FA}=$ filamentous algae; $\mathrm{UCA}=$ unicellular or colonial algae; $\mathrm{TG}=$ trophic group; $\mathrm{F}-\mathrm{D}=$ fine-detritivores; $\mathrm{O}=$ omnivores; $\mathrm{C}-\mathrm{D} / \mathrm{H}=$ coarse-detritivores $/$ herbivores; $\mathrm{S}-\mathrm{P}=$ specialist-predators; $\mathrm{G}-\mathrm{P}=$ generalist-predators .

\begin{tabular}{|c|c|c|c|c|c|c|c|c|c|}
\hline \multirow{2}{*}{ Taxon } & \multirow{2}{*}{$\mathbf{N}$} & \multicolumn{8}{|c|}{ Food item } \\
\hline & & FPOM & CPOM & FUN & $\mathrm{Al}$ & NAI & FA & UCA & TG \\
\hline Chironominae & 90 & 98.7 & 0 & 0.2 & 0 & 0 & 0 & 1,1 & F-D \\
\hline Orthocladiinae & 90 & 98.7 & 0 & 0.1 & 0 & 0 & 1.2 & 0 & F-D \\
\hline Tanypodinae & 60 & 73.2 & 0 & 1.2 & 25.5 & 0.1 & 0 & 0.2 & $\mathrm{O}$ \\
\hline Ceratopogonidae & 58 & 99 & 0 & 0.6 & 0 & 0 & 0.3 & 0.1 & F-D \\
\hline Simulium & 41 & 100 & 0 & 0 & 0 & 0 & 0 & 0 & F-D \\
\hline Macronema & 13 & 13.6 & 86.4 & 0 & 0 & 0 & 0 & 0 & $\mathrm{C}-\mathrm{D} / \mathrm{H}$ \\
\hline Smicridea & 27 & 59.2 & 20.7 & 4.5 & 13.3 & 0.4 & 1.8 & 0.1 & $\mathrm{O}$ \\
\hline Hetaerina/Mnesarete & 41 & 1 & 0 & 0.2 & 98.8 & 0 & 0 & 0 & S-P \\
\hline Phyllocycla & 13 & 0.4 & 0 & 0 & 99.6 & 0 & 0 & 0 & S-P \\
\hline Progomphus & 4 & 0 & 0 & 0 & 100 & 0 & 0 & 0 & S-P \\
\hline Peruviogomphus & 3 & 0 & 0 & 0 & 100 & 0 & 0 & 0 & S-P \\
\hline Caenis & 33 & 94 & 0 & 5.8 & 0 & 0 & 0.2 & 0 & F-D \\
\hline Traverhyphes & 75 & 93.2 & 3.2 & 2.3 & 0 & 0 & 1,1 & 0.2 & F-D \\
\hline Tricorythodes & 45 & 86.1 & 7.9 & 2.2 & 0 & 0 & 3.2 & 0.6 & F-D \\
\hline Farrodes & 52 & 93.5 & 1.1 & 4.7 & 0 & 0 & 0.7 & 0 & F-D \\
\hline Ulmeritoides & 3 & 93.3 & 0.3 & 4.3 & 0 & 0 & 0.4 & 1.7 & F-D \\
\hline Americabaetis & 78 & 95.2 & 0.3 & 4,1 & 0 & 0 & 0.4 & 0 & F-D \\
\hline Paracloeodes & 20 & 95.3 & 0.5 & 2.2 & 0 & 0 & 2 & 0 & F-D \\
\hline Waltzohyphius & 16 & 98.5 & 0 & 1.3 & 0 & 0 & 0.1 & 0.1 & F-D \\
\hline Apobaetis & 13 & 98.6 & 0 & 1.3 & 0 & 0 & 0.1 & 0 & F-D \\
\hline Heterelmis & 35 & 81.4 & 12.6 & 6 & 0 & 0 & 0 & 0 & F-D \\
\hline Hexacylloepus & 19 & 90.9 & 1.8 & 7.3 & 0 & 0 & 0 & 0 & F-D \\
\hline Microcylloepus & 26 & 93.5 & 1.1 & 5.4 & 0 & 0 & 0 & 0 & F-D \\
\hline Macrelmis & 12 & 94.1 & 0 & 5.9 & 0 & 0 & 0 & 0 & F-D \\
\hline Neoelmis & 4 & 96.2 & 0 & 3.8 & 0 & 0 & 0 & 0 & F-D \\
\hline Macrobrachium & 26 & 10.4 & 6.5 & 0.3 & 79.9 & 0.3 & 2.6 & 0 & G-P \\
\hline Belostoma* & - & - & - & - & - & - & - & - & G-P \\
\hline Limnocoris* $^{*}$ & - & - & - & - & - & - & - & - & G-P \\
\hline
\end{tabular}

${ }^{*}$ The diet of hemipterans could not be determined because they are fluid-feeders. Their trophic group was assigned based on Nieser \& Melo (1997). 
Macroinvertebrates were classified into five trophic groups according to the similarity analysis (Figure 2): fine-detritivores (fed mostly on fine particulate organic matter - FPOM), coarse-detritivores/herbivores (fed mostly on coarse particulate organic matter - CPOM - and plant detritus), omnivores (fed on detritus and/or algae and also preyed), specialist-predators (preyed on aquatic insects only), and generalist-predators (preyed on other animals as well).

The fine-detritivores group comprised the majority of the sampled taxa $(64.3 \%)$, including all Ephemeroptera, Elmidae, and most Diptera. The second most representative group (with 14.3\% of all taxa) was that of specialist-predators, with genera of the Calopterygidae and Gomphidae families that preyed almost exclusively on aquatic insects. Macrobrachium represented the generalist-predators, feeding on microcrustaceans, aquatic mites, annelids, and aquatic insects, associated with algae, organic matter and fungi. Although the diet of the hemipterans Belostoma and Limnocoris could not be determined, they were classified as generalist-predators based on

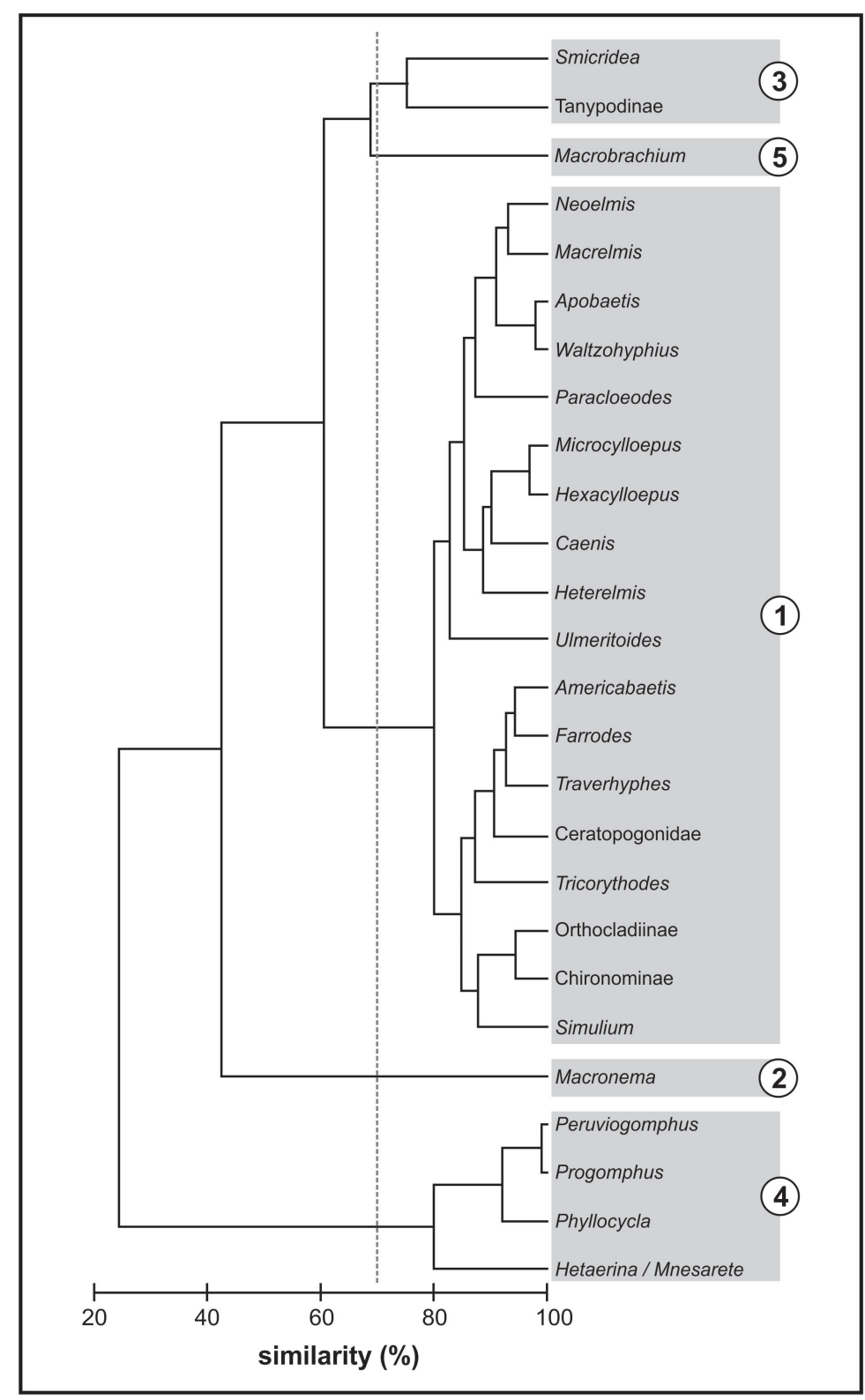

Figure 2. Dendrogram representing the similarity in macroinvertebrate diet and the trophic groups they belong to. The grey line represents the $70 \%$ similarity cut used to define trophic groups. The numbered gray boxes represent the following trophic groups: 1 = fine-detritivores; 2 = coarse-detritivores/herbivores; 3 = omnivores; 4 = specialist-predators; $5=$ generalist-predators. The cluster was obtained through UPGMA method using the Bray-Curtis similarity coefficient. 
literature data (Nieser \& Melo, 1997). The caddisfly Macronema was unique in the coarse-detritivore/ herbivore group and also the only one that presented a specialized diet, feeding exclusively on plant material and CPOM. Smicridea and Tanypodinae, on the other hand, fed on detritus but also preyed, thus being classified into the omnivores group.

Fine-detritivores were also the prominent group in terms of abundance, comprising $93.2 \%$ of samples specimens, followed by omnivores (4.3\%), generalist-predators $(1.5 \%)$, specialist-predators $(0.7 \%)$, generalist-detritivores $(0.2 \%)$, and coarse-detritivore/herbivores $(0.1 \%)$. Although taxa were classified into these groups, among-stream variation on diet composition (and thus classification into different trophic groups) was observed for Macrobrachium (classified as generalist-predator or specialist-predator, depending on the stream) Tanypodinae (omnivores, fine-detritivores or generalist-predators) and Smicridea (omnivores or fine-detritivores).

\section{Discussion}

Insects were predominant in the sampled streams, comprising six of the seven macroinvertebrate orders sampled, with dipterans, mayflies, and odonates as the most numerous ones. For these organisms in general (with exception of odonates), FPOM was by far the most consumed food item. Such findings have been commonly reported elsewhere (Palmer et al., 1993; Shieh et al., 2002; Tomanova et al., 2006; Carvalho \& Uieda, 2009; Ocon et al., 2013; Ceneviva-Bastos \& Casatti, 2014) and reinforce the importance of this food resource as a key component of lotic ecosystems food webs (Acuña et al., 2005; Ceneviva-Bastos \& Casatti, 2014).

Accordingly, the fine-detritivores was the most abundant and species-rich trophic group, indicating that FPOM is likely a non-limiting resource of great abundance. Organic matter can have autochthonous or allochthonous origin and is known to maintain highly diverse systems (Rosemond et al., 1998; Moore et al., 2004). The preference for abundant resources as such can be considered an advantage in unstable environments as streams (Allan \& Castilho, 2007) because less time and energy are spent in searching for food (Optimal Foraging Theory, MacArthur \& Pianka, 1966).

Animal origin items are also considered an abundant resource, though with higher caloric and protein value, what makes it high-quality food that is used by many organisms (Cummins \&
Klug, 1979). Represented by aquatic insects, this food category was the second most consumed by macroinvertebrates, especially odonates. The diet of odonates (classified as specialist-predators) was specialized in aquatic insects, though the consumption of insects from different orders indicates little diet overlap, as in other studies (Motta \& Uieda, 2004; Carvalho \& Uieda, 2009). Gomphidae dragonflies, for example, burrow in the substrate (Carvalho \& Nessimian, 1998) and preyed mostly on chironomids, whereas Calopterygidae damselflies are climbers (Assis et al., 2004) and preyed mostly on mayflies.

Shrimps were classified as generalist-predators because they used a variety of food items among which animals were predominant. Since they usually consume detritus and animal and vegetal fragments, they are commonly classified as opportunistic omnivores, with a trend to carnivory (Roy $\&$ Singh, 1997; Collins \& Paggi, 1998; Lima et al., 2014). The predatory hemipterans, such as Belostoma and Limnocoris, were also classified as generalist-predators for being able to feed on a high prey diversity, such as fish, tadpoles, aquatic and terrestrial insects and vertebrates (Nieser \& Melo, 1997).

Coarse particulate organic matter and plant detritus were found in most caddisfly guts, although Macronema diet was more specialized on plant material (being classified into the coarse-detritivore/ herbivore group). Macronema individuals fed mostly on plant fragments of equal size, probably by taking small and regular bites (Flint Junior, 1983) on leaves and aquatic roots. Conversely, Smicridea was classified as a generalist-detritivore for presenting a broad diet that includes from algae, detritus and fungi to aquatic insects, as found in other studies (Flint Junior, 1983; Gil et al., 2008).

The classification of aquatic insects into functional feeding groups as proposed by Merritt $\&$ Cummins (1996) is not appropriate for most tropical taxa (although it is frequently used), especially when trying to understand ecosystem function under a trophic perspective approach. Besides underestimating invertebrate trophic plasticity, it is frequent that a function is attributed to a taxon that is not exerting it in a given environment (Rosi-Marshall \& Wallace, 2002; Dangles, 2002). For example, to assume that all Tanypodinae are predators would be to underestimate the energetic importance of algae and organic matter. In our study, they were omnivorous that fed mostly on detritus and also consumed other animals, not the 
other way around. Hence, we highlight the necessity of conducting gut content analysis to properly assess what invertebrates eat instead of using inferences from literature data only, especially when it comes to tropical ecosystems.

Tropical stream fish, for instance, present broad trophic plasticity and are potentially capable of using whichever food resources are available in the environment that adequate to their mouth apparatus and digestive capability (Gerking, 1994). The same is applicable to invertebrates, which usually feed on the most abundant food resources (Ceneviva-Bastos \& Casatti, 2014). In fact, this generalist and opportunistic feeding habit is a common strategy of many aquatic invertebrates, even from temperate streams (Mihuc \& Minshall, 1995). Such strategy facilitates their adaption to changes in food availability (Motta \& Uieda, 2004), though it hinders their classification into consistent trophic categories. Our data confirm such difficulty, since trophic groups of some taxa (i.e. Macrobrachium, Smicridea and Tanypodinae) varied among streams, even considering that all streams had similar structural characteristics.

According to the "River habitat templet" theory (Townsend \& Hildrew, 1994), the function of a species in an ecosystem is subject to environmental conditions. Therefore, while behavioral and detailed morphological data are still unavailable, we recommend using gut content analysis (instead of literature-based functional feeding groups) to depict species roles in the ecosystems and to assess the structure and function of tropical running waters. Finally, since the condition of the studied streams implies some level of physical degradation, it is presumable to expect trophic groups to be different in better-preserved streams.

\section{Conclusion}

Fine particulate organic matter was the most abundant and frequent food resource used by the studied community, reinforcing the importance of this food resource in tropical streams, while the variation in trophic groups observed for some taxa reinforces the generalist nature of aquatic macroinvertebrates. The use of diversified food sources by invertebrates hinders the attempts of making general assumptions regarding their trophic ecology. Ontogenetic, seasonal, spatial and individual diet shifts, along with a broad repertory of feeding tactics, are examples of such flexibility, making it difficult to classify invertebrates into consistent trophic categories and establish patterns to compare ecosystems (Cummins, 1973).

Hence, the use of diet analysis to assess macroinvertebrate trophic structure and resource use can guide the path through a functional perspective of each ecosystem. Notwithstanding, further basic studies on tropical invertebrates taxonomy, ecology, behavior and morphology is needed to assess their functional roles in a more accurate way. Studies that empirically determined macroinvertebrate diet in Brazil, for instance, are very scarce, even though such knowledge is of primal importance to the feasibility of creating a functional feeding group classification that could be extrapolated to other Neotropical streams (Tomanova et al., 2006). In this context, this study provides an important contribution to current knowledge on macroinvertebrate feeding by providing an accurate data set of their trophic ecology.

\section{Acknowledgements}

We are grateful to Laboratório de Ictiologia colleagues for their help during fieldwork and the Departamento de Zoologia e Botânica IBILCE-UNESP for facilities, IBAMA for collecting license, landowners for permission to conduct research on their properties. We thank FAPESP (BNS grant number 2012/06041-8, MCB grant number 2011/11641-1), CAPES (ARM, MCB current funding - PNPD at Biosciences Graduate Program, UNESP/Assis) and CNPQ (LC grant number 301755/2013-2) for funding this research.

\section{References}

ACUÑA, V., MUÑOZ, I., GIORGI, A., OMELLA, M., SABATER, F. and SABATER, S. Drought and post drought recovery cycles in an intermittent Mediterranean stream: structural and functional aspects. Journal of the North American Benthological Society, 2005, 24(4), 919-933. http://dx.doi. org/10.1899/04-078.1.

ALLAN, J.D. and CASTILHO, M.M. Stream ecology: structure and function of runing Waters. 2nd ed Londres: Editora Springer, 2007, 436 p.

ASSIS, J.C.F., CARVALHO, A.L. and NESSIMIAN, J.L. Composição e preferência por micro-hábitat de imaturos de Odonata (Insecta) em um trecho de baixada do Rio Ubatiba, Maricá-RJ, Brasil. Revista Brasileira de Entomologia, 2004, 48(2), 273-282. http://dx.doi.org/10.1590/S008556262004000200017.

BISPO, P.C., OLIVEIRA, L.G., BINI, L.M. and SOUSA, K.G. Ephemeroptera, Plecoptera and Trichoptera assemblages from riffles in mountain 
streams of Central Brazil: environmental factors influencing the distribution and abundance of immatures. Brazilian Journal of Biology = Revista Brasileira de Biologia, 2006, 66(2b), 611-622. http:// dx.doi.org/10.1590/S1519-69842006000400005. PMid:16906293.

BOUlton, A.J., BOYERO, L., COVICH, A.P., DOBSON, M., LAKE, S. and PEARSON, R. Are tropical streams ecologically different from temperate streams? In D. Dudgeon. Tropical stream Ecology. London: Elsevier, 2008, 304 p.

BOYERO, L., RAMÍREZ, A., DUdGEON, D. and PEARSON, R.G. Are tropical streams really different? Journal of the North American Benthological Society, 2009, 28(2), 397-403. http://dx.doi. org/10.1899/08-146.1.

CALLISTO, M., MORENO, P. and BARBOSA, F.A.R. Habitat diversity and benthic functional trophic groups at Serra do Cipó, Southeast Brazil. Brazilian Journal of Biology = Revista Brasileira de Biologia, 2001, 61(2), 259-266. http://dx.doi.org/10.1590/ S0034-71082001000200008. PMid:11514893.

CARVALHO, A.L. and NESSIMIAN, J.L. Odonata do Estado do Rio de Janeiro, Brasil: hábitats e hábitos das larvas. In J.L. Nessimian and A.L. Carvalho, eds. Ecologia de insetos aquáticos. Rio de Janeiro: PPGEUFRJ, 1998 pp. 2-28. Séries Oecologia Brasiliensis, vol. 5.

CARVALHO, E.M. and UIEDA, V.S. Diet of invertebrates sampled in leaf-bags incubated in a tropical headwater stream. Zoologia, 2009, 26(4), 694-704. http://dx.doi.org/10.1590/S198446702009000400014.

CASATTI, L., FERREIRA, C.P. and CARVALHO, F.R. Grass-dominated stream sites exhibit low fish species diversity and dominance by guppies: an assessment of two tropical pasture river basins. Hydrobiologia, 2009, 632(1), 273-283. http://dx.doi.org/10.1007/ s10750-009-9849-y.

CENEVIVA-BASTOS, M. and CASATTI, L. Shading effects on community composition and food web structure of a deforested pasture stream: evidences from a field experiment in Brazil. Limnologica, 2014, 46, 9-21. http://dx.doi.org/10.1016/j. limno.2013.11.005.

CHESHIRE, L., BOYERO, L. and PEARSON, R.G. Food webs in tropical Australian streams: shredders are not scarce. Freshwater Biology, 2005, 50(5), 748-769. http://dx.doi.org/10.1111/j.13652427.2005.01355.x.

CLARKE, A., MAC NALLY, R., BOND, N. and LAKE, P.S. Macroinvertebrate diversity in headwater streams: a review. Freshwater Biology, 2008, 53(9), 1707-1721. http://dx.doi.org/10.1111/j.13652427.2008.02041.x.
CLARKE, K.R. and GORLEY, R.N. PRIMER v6 user manual/tutorial. Plymouth: PRIMER-E, 2006, 91 p.

COLLINS, P.A. and PAGGI, J.C. Feeding ecology of Macrobrachium borelli (Nobili) (Decapoda:Palaemonidae) in the flood valley of the river Paraná, Argentina. Hydrobiologia, 1998, 362(1-3), 21-30. http://dx.doi. org/10.1023/A:1003166116086.

COUCEIRO, S.R.M., HAMADA, N., FORSBERG, B.R. and PADOVESI-FONSECA, C. Trophic structure of macroinvertebrates in Amazonian streams impacted by antropogenic siltation. Austral Ecology, 2011, 36, 628-637.

CUMMINS, K.W. and KLUG, M.J. Feeding ecology of stream invertebrates. Annual Review of Ecology and Systematics, 1979, 10(1), 147-172. http://dx.doi. org/10.1146/annurev.es.10.110179.001051.

CUMMINS, K.W. Trophic relations of aquatic insects. Annual Review of Entomology, 1973, 18(1), 183-206. http://dx.doi.org/10.1146/annurev. en.18.010173.001151.

CUMMINS, K.W., MERRITT, R.W. and ANDRADE, P.C.N. The use of invertebrate functional groups to characterize ecosystem attributes in selected streams and rivers in south Brazil. Studies on Neotropical Fauna and Environment, 2005, 40(1), 69-89. http:// dx.doi.org/10.1080/01650520400025720.

DANGLES, O. Functional plasticity o benthic macroinvertebrates: implications for trophic dynamics in acid streams. Canadian Journal of Fisheries and Aquatic Sciences, 2002, 59(9), 15631573. http://dx.doi.org/10.1139/f02-122.

DOMÍNGUEZ, E. and FERNÁNDEZ, H.R. Macroinvertebrados bentônicos sudamericanos: sistemética y biologia. Tucumán: Fundación Miguel Lillo, 2009, 654 p.

FLINT JUNIOR, O.S. Studies of Neotropical caddisflies, XXXIII: new species from Austral South America (Trichoptera). Smithsonian Contributions to Zoology, 1983, 377(377), 1-100. http://dx.doi. org/10.5479/si.00810282.377.

FROEHLICH, C.G. Guia on-line: identificação de larvas de Insetos Aquáticos do Estado de São Paulo [online]. 2007 [viewed 2016 Jan. 25]. Available from: http:// sites.ffclrp.usp.br/aguadoce/guiaonline

GERKING, S.D. Feeding ecology of fish. San Diego: Academic Press, 1994, 416 p.

GESSNER, M.O. and CHAUVET, E. A case for using litter breakdown to access functional stream integrity. Ecological Applications, 2002, 12(2), 498-510. http:// dx.doi.org/10.1890/1051-0761(2002)012[0498:AC FULB]2.0.CO;2.

GIL, M.A., TRIPOLE, S. and VALLANIA, E.A. Feeding habits of Smicridea (Rhyacophylax) dythyra Flint, 1974 (Trichoptera: Hydropsychidae) larvae in 
the Los Molles stream (San Luis - Argentina). Acta Limnologica Brasiliensia, 2008, 20(1), 1-4.

GONÇALVES JÚNIOR, J.F., GRAÇA, M.A.S. and CALLISTO, M. Leaf-litter breakdown in 3 streams in temperate, Mediterranean, and tropical Cerrado climates. Journal of the North American Benthological Society, 2006, 25(2), 344-355. http:// dx.doi.org/10.1899/0887-3593(2006)25[344:LBI SIT]2.0.CO;2.

INSTITUTO DE PESQUISASTECNOLÓGICAS DO ESTADO DE SÃO PAULO - IPT. Diagnóstico da situação atual dos Recursos Hidricos e estabelecimento de diretrizes técnicas para a elaboração do plano da Bacia Hidrográfica do São José dos Dourados. São Paulo: IPT, 2000, 119 p. [Relatório n. 40675].

KRONKA, F.J.N., MATSUKUMA, C.K., NALON, M.A., DELCALI, I.H., ROSSI, M., MATTOS, I.F.A., SHINIKE, M.S. and PONTINHAS, A.A.S. Inventário florestal do Estado de São Paulo. São Paulo: Instituto Florestal, 1993, 199 p.

LIMA, J.F., GARCIA, J.S. and SILVA, T.C. Natural diet and feeding habits of a freshwater prawn (Macrobrachium carcinus: Crustacea, Decapoda) in the estuary of the Amazon River. Acta Amazonica, 2014, 44(2), 235-244. http://dx.doi.org/10.1590/ S0044-59672014000200009.

MACARTHUR, R.H. and PIANKA, E.R. On optimal use of a patchy environment. American Naturalist, 1966, 100(916), 603-609. http://dx.doi. org/10.1086/282454.

MALMQVIST, B. Aquatic invertebrates in riverine landscapes. Freshwater Biology, 2002, 47(4), 679-694. http://dx.doi.org/10.1046/j.13652427.2002.00895.x.

MATHURIAU, C. and CHAUVET, E. Breakdown of leaf litter in a Neotropical stream. Journal of the North American Benthological Society, 2002, 21(3), 384-396. http://dx.doi.org/10.2307/1468477.

MERRITT, R.W. and CUMMINS, K.W. An introduction to the aquatic insects of North America. Dubuque: Kendall/Hunt, 1996, 862 p.

MIHUC, T.B. and MINSHALL, G.W. Trophic generalists vs. trophic specialists: implications for food web dynamics in post-fre streams. Ecology, 1995, 76(8), 2361-2372. http://dx.doi. org/10.2307/2265813.

MOORE, J.C., BERLOW, E.L., COLEMAN, D.C., RUITER, P.C., DONG, Q., HASTINGS, A., JOHNSON, N.C., MCCANN, K.S., MELVILLE, K., MORIN, P.J., NADELHOFFER, K., ROSEMOND, A.D., POST, D.M., SABO, J.L., SCOW, K.M., VANNI, M.J. and WALL, D.H. Detritus, trophic dynamics and biodiversity. Ecology Letters, 2004, 7(7), 584-600. http://dx.doi. org/10.1111/j.1461-0248.2004.00606.x.
MOTTA, R.L. and UIEDA, V.S. Diet and trophic groups of an aquatic insect community in a tropical stream. Brazilian Journal of Biology = Revista Brasileira de Biologia, 2004, 64(4), 809-817. http:// dx.doi.org/10.1590/S1519-69842004000500010. PMid:15744421.

MOULTON, T.P. Saúde e integridade do ecossistema e o papel dos insetos aquáticos. In J.L. Nessimian and A.L. Carvalho, eds. Ecologia de insetos aquáticos. Rio de Janeiro: PPGE-UFRJ, 1998, pp. 281-298. Séries Oecologia Brasiliensis, vol. 5.

MUGNAI, R., NESSIMIAN, J.L. and BAPTISTA, D.F. Manual de Identificação de Macroinvertebrados do Estado do Rio de Janeiro. Rio de Janeiro: Technical Books, 2010, 176 p.

NAKANO, S. and MURAKAMI, M. Reciprocal subsidies: dynamics interdependence between terrestrial and aquatic food webs. Proceedings of the North American Society, 2001, 98(1), 166170. http://dx.doi.org/10.1073/pnas.98.1.166. PMid:11136253.

NALON, M., MATTOS, I.F.A. and CORRÊAFRANCO, G.A.D. Meio físico e aspectos da fragmentação da vegetação. In R.R. Rodrigues and V.L.R. Bononi. Diretrizes para a conservação e restauração da biodiversidade no Estado de São Paulo. São Paulo: Instituto de Botânica/FAPESP, 2008, pp. 16-21.

NIESER, N. and MELO, A.L. Os heterópteros aquáticos de Minas Gerais: guia Introdutório com chave de Identificação para as espécies de Nepomorpha e Gerromorpha. Belo Horizonte: Editora UFMG, 1997, $180 \mathrm{p}$.

OCON, C., OOSTEROM, M.V.L., MUÑOZ, M.I. and RODRIGUES-CAPÍTULO, A. Macroinvertebrates trophic responses to nutrient addition in a temperate stream in South America. Fundamental and Applied Limnology, 2013, 182(1), 17-30. http://dx.doi. org/10.1127/1863-9135/2013/0382.

OLIVEIRA, A.L.H. and NESSIMIAN, J.L. Spatial distribution and functional feeding groups of aquatic insect communities in Serra da Bocaina streams, southeastern Brazil. Acta Limnologica Brasiliensia, 2010, 22(4), 424-441. http://dx.doi.org/10.4322/ actalb.2011.007.

OLIVEIRA, L.G. and FROEHLICH, C.G. Diversity and community structure of aquatic insects (Ephemeroptera, Plecoptera and Trichoptera) in a southeastern Brazilian mountain stream. Acta Limnologica Brasiliensia, 1997, 9, 139-148.

PALMER, C., O'KEEFFE, J., PALMER, A., DUNNE, T. and RADLOFF, S. Macroinvertebrate functional feeding groups in the middle and lower reaches of the Buffalo River eastern Cape, South Africa. Freshwater Biology, 1993, 29(3), 441-453. http:// dx.doi.org/10.1111/j.1365-2427.1993.tb00778.x. 
PASCOAL, C., CÁSSIO, F., MARCOTEGUI, I.A., SANZ, B. and GOMES, P. Role of fungi, bacteria, and invertebrates in leaf litter breakdown in a polluted river. Journal of the North American Benthological Society, 2005, 24(4), 784-797. http:// dx.doi.org/10.1899/05-010.1.

PASSOS, M.I.S., NESSIMIAN, J.L. and FERREIRA JUNIOR, N.F. Chaves para identificação dos gêneros de Elmidae (Coleoptera) ocorrentes no Estado do Rio de Janeiro, Brasil. Revista Brasileira de Entomologia, 2007, 51(1), 42-53. http://dx.doi.org/10.1590/ S0085-56262007000100008.

RAMÍREZ, A. and GUTIÉRREZ-FONSECA, P.E. Functional feeding groups of aquatic insect families in Latin America: a critical analysis and review of existing literature. Revista de Biologia Tropical, 2014, 62(2 Suppl 2), 155-167. http://dx.doi.org/10.15517/ rbt.v62i0.15785. PMid:25189076.

RICKLEFS, R.E. A economia da natureza. 6. ed. Rio de Janeiro: Editora Guanabara Koogan, 2010, 545 p.

RODRIGUES, R.R. and LEITÃO FILHO, H.F. Matas ciliares: conservação e recuperação. São Paulo: EDUSP/ FAPESP, 2000, $320 \mathrm{p}$.

ROONEY, N., MCCANN, K., GELLNER, G. and MOORE, J.C. Structural asymmetry and stability of diverse food webs. Nature, 2006, 442(7100), 265-269. http://dx.doi.org/10.1038/nature04887. PMid:16855582.

ROSEMOND, A.D., PRINGLE, C.M. and RAMÍREZ, A. Macroconsumer effects on insect detritivores and detritus processing in a tropical stream. Freshwater Biology, 1998, 39(3), 515-523. http://dx.doi. org/10.1046/j.1365-2427.1998.00301.x.

ROSI-MARSHALL, E.J. and WALLACE, B. Invertebrate food webs along stream resource gradient. Freshwater Biology, 2002, 47(1), 129-141. http://dx.doi. org/10.1046/j.1365-2427.2002.00786.x.

ROY, D. and SINGH, D.S.R. The food and feeding habits of a freshwater prawn Macrobrachium choprai. Asian Fisheries Science, 1997, 10, 51-63.

SEGURA, M.O., VALENTE-NETO, F. and FONSECA-GESSNER, A.A. Elmidae (Coleoptera, Byrrhoidea) larvae in the state of São Paulo, Brazil: Identification key, new records and distribution. ZooKeys, 2011, 151(151), 53-74. http://dx.doi. org/10.3897/zookeys.151.1879. PMid:22368452.
SHIEH, S., WARD, J. and KONDRATIEFF, B. Energy flow through macroinvertebrates in a polluted plains stream. Journal of the North American Benthological Society, 2002, 21(4), 660-675. http://dx.doi. org/10.2307/1468437.

SILVA, A.M., CASATTI, L., ALVARES, C.A.A., LEITE, A.M., MARTINELLI, L.A. and DURRANT, S.F. Soil loss and habitat quality in streams of a meso-scale river basin. Scientia Agricola, 2007, 64(4), 336-343. http://dx.doi.org/10.1590/S010390162007000400004

TERESA, F.B. and CASATTI, L. Importância da vegetaçáo ripária degradada em regiâo intensamente desmatada no sudeste do Brasil: um estudo com peixes de riacho. Pan-American Journal of Aquatic Sciences, 2010, 5(3), 444-453.

TOMANOVA, S., GOITIA, E. and HELEŠIC, J. Trophic levels and functional feeding groups of macroinvertebrates in neotropical streams. Hydrobiologia, 2006, 556(1), 251-264. http://dx.doi. org/10.1007/s10750-005-1255-5.

TOWNSEND, C.R. and HILDREW, A.G. Species traits in relation to a habitat templet for river systems. Freshwater Biology, 1994, 31(3), 265-275. http:// dx.doi.org/10.1111/j.1365-2427.1994.tb01740.x.

VANNOTE, R.L., MINSHALL, G.W., CUMMINS, K.W., SEDELL, J.R. and CUSHING, C.E. The river continuum concept. Canadian Journal of Fisheries and Aquatic Sciences, 1980, 37(1), 130-137. http:// dx.doi.org/10.1139/f80-017.

WANTZEN, K.M. and WAGNER, R. Detritus processing by invertebrate shredders: a neotropicaltemperate comparison. Journal of the North American Benthological Society, 2006, 25(1), 214-230. http:// dx.doi.org/10.1899/0887-3593(2006)25[216:DPB ISA]2.0.CO;2.

WRIGHT, M.S. and COVICH, A.P. The effect of macroinvertebrate exclusion on leaf breakdown rates in a tropical headwater stream. Biotropica, 2005, 37(3), 403-408. http://dx.doi.org/10.1111/j.17447429.2005.00053.x.

Received: 25 January 2016 Accepted: 01 September 2016 